\author{
TADEuSz MARSZAŁ \\ University of Lodz, Poland
AgNIESZKA OGRODOWCZYK
University of Lodz, Poland

\title{
Research Directions and Achievements of Polish Geography of Construction
}

\begin{abstract}
Although the second half of the 20th century is the period of development of economic geography in Poland, in the first post-war decades geography of construction did not function as a separate geographical subdivision. More significant development of spatial research in this field was brought about a quarter of a century ago. In the article devoted to the problems of geography of construction in Poland, the subject scope, main directions of research and the achievements of this sub-discipline are discussed. Geography of construction is a branch of economic geography, which examines spatial aspects of construction and assembly 'production', with special attention to spatial organisation of investment processes, as well as conditions and effects of location and spatial structure of construction investments. The literature review allows for isolating the main directions, among which the following can be listed: conditions for the development of construction of different functions, also in the context of the accompanying phenomena (e.g. in the social sphere), location factors and effects of construction investments, as well as research devoted to the spatial structure of construction projects and their links with geographical environment. Research topics of geography of construction are part of the spatial processes within the interests of other geographic sub-disciplines, as well as of related social, economic and even technical disciplines. The achievements of Polish geography of construction of the last quarter of a century are important from the point of view of a better recognition of the conditions and course of the socio-economic transformation in Poland in different contexts and different spatial scales.
\end{abstract}

Keywords: Polish geography of construction; research achievements and directions; subject of research

Received: 22 May 2018

Accepted: 17 July 2018

\section{Suggested citation:}

Marszał, T., Ogrodowczyk, A. (2018). Research Directions and Achievements of Polish Geography of Construction. Prace Komisji Geografii Przemysłu Polskiego Towarzystwa Geograficznego [Studies of the Industrial Geography Commission of the Polish Geographical Society], 32(4), 135-148. https://doi. org/10.24917/20801653.324.8

\section{INTRODUCTION}

The second half of the 20th century brought dynamic development of economic geography in Poland, in particular geography of industry and geography of transport, both related to the material sphere of economic activity. However, Polish geographical 
literature in the early post-war decades barely contained any reference to such a term as geography of construction. It was not until the conference of the Industrial Geography Commission of the Polish Geographical Society, which took place in Krakow at the turn of the 1970s and 1980s, that L. Straszewicz proposed the inclusion of a rather marginally treated theme of geography of construction. In the article published after this conference, when analysing the role of geography of industry in the system of geographic sciences, L. Straszewicz suggested:

"Specialists in industrial issues are sometimes limited in their research... only to the processing industry... On the other hand, construction is also rarely included in industry; in our planning and statistical practice it is generally thrown into a separate housing sector. In my opinion, despite many doubts and reservations, geography of industryshould include all these three sections (i.e. also mine industry), although they are characterised not only by the diversity of the subject matter, but also very different issues, and - what may be the most important- different research methods" (Straszewicz, 1986: 28).

The argument for such a solution to situating the problems of construction was that together with the processing industry it belongs to the second sphere of human economic activity and is subject to the same laws that tie construction with industry, especially industry of investment goods. The difference concerns the nature of the work and the type of a finished product which cannot be subject to movement and is quite a different merchandise on the specific service and real estate market. As L. Straszewicz writes, "in geographical practice so far no one has dealt with construction thoroughly, leaving this importantsector of the national economy beyond the sphere of interests of economic geography. I think, however, that there is no more serious reason our discipline (i.e. geography of industry - added by the authors) should not include constructionas a special phase of industry" (Straszewicz, 1986: 29).

This demand for broader integration of construction issues into geographical research within the sub-discipline of geography of industry did not receive much response, as evidenced by the very carefully reviewed achievements of Polish geography of industry at the end of the 20th century (Misztal, Zioło, 1998; Marszał, 2001). The next decades, and especially the last quarter of the century, have brought significant development of spatial research in the field of construction.

Taking the above into account, the article discusses several issues that relate to: (1) the scope of the subject and object of research of geography of construction, (2) the main directions of research carried out within this geographical subdivision in Poland, and (3) the achievements of Polish geography of construction.

\section{OBJECT OF RESEARCH IN GEOGRAPHY OF CONSTRUCTION}

Presentation of the achievements of geography of construction, and more broadly spatial research on the issues of construction, requires in the first place specifying the merits of the subject of research of this relatively young subdivision of socio-economic geography.

Construction is part of the national economy, in which purposeful and conscious human activity adapts natural resources for human needs through the implementation of construction projects. Construction investments are a specific kind of economic activity, the aim of which is to construct a building with specific utility characteristics 
and in a specific place, as well as the reconstruction, extension and superstructure of a building ${ }^{1}$. The notion of a construction project, referring to the result of this activity, can mean the effect of investment. On the other hand, in economic terms, it can be understood as an economic burden incurred for maintaining, creating or increasing capital, which has the form of a construction object.

Construction investment, treated as a synonym of a construction process, is a complex and multi-stage activity serving the implementation of a construction project and includes not only the phase of physical implementation of a building, but also the necessary accompanying measures required by law, such as:

- development of a construction project (development of the plot, as well as architectural and construction project),

- obtaining an administrative decision enabling the commencement of construction. $^{2}$

For construction plots or areas where construction is planned, it is necessary to design and implement appropriate development (before putting objects into service) ${ }^{3}$. The obligatory element of the construction process is the investment's characteristics including, in addition to the land development and building characteristics (design and dimensions of the planned structures), the legal status of the property (including planning as well as protection and conservation), technical infrastructure needs (availability of utilities), transportation accessibility, technical parameters and geotechnical conditions of the investment and its impact on the environment ${ }^{4}$. The key issue determining the construction investment is compliance of the construction project with the provisions of the local spatial development plan (or with the decision on land development conditions, as well as environmental protection requirements) and building regulations.

Construction objects - whose inherent feature is permanent connection to the ground (so they are unmovable) - may take the form of (a) structures, i.e. objects not singling out the inner space intended for living beings, but which are not objects of small architecture, (b) buildings, i.e. cubature objects with foundations and a roof, separated from space by means of building partitions and used for various purposes by man, and (c) objects of small architecture.

As part of such defined construction, the following can be distinguished based on the purpose and functions: housing (single-family, multi-family, and collective), service and municipal (technical infrastructure and small architecture), industrial construction, communication/road, agricultural and water (marine and inland).

Construction, understood both as the investment process and the effect of this process, is the subject of research of many academic disciplines falling within the scope of both technical and social knowledge. What makes geography stand out among them is conducting spatial analyses. Geography of construction is thus a branch of economic geography, which examines: (a) the spatial aspects of the construction and assembly 'production' (related to site preparation, raising structures and buildings, performing

\footnotetext{
${ }^{1}$ See Article 3 of the Construction Law Act of 1994.

${ }^{2}$ An administrative decision requires a change of land development consisting in the construction of a building or other construction works, as well as a change in the use of the building or its part, if there is no local zoning plan.

${ }^{3}$ Cf. Article 6 of the 1994 Construction Law Act.

${ }^{4}$ Cf. Article 52, Item 1, Point 2 of the Spatial Planning and Development Act of 2003.
} 
installation construction, and execution of finishing works), and especially the spatial organisation of investment processes, and (b) conditions and effects of location and spatial structure of construction investments.

The above-presented definition of the research area of geography of construction, although its theoretical dimension should not raise doubts, in practice does not always allow assigning specific scientific achievements to a given sub-discipline. This is primarily determined by the nature of the construction activity, which very closely fits into the spatial processes remaining in the interest of other geographic sub-disciplines, as well as the related social, economic and even technical disciplines. An example can be geography of transport, industry and settlement, as well as spatial management and urban planning. Spatial analysis of construction fits perfectly within the issues of spatial development, revitalisation, location of investments, housing policy and many other issues often undertaken in an interdisciplinary approach.

This specificity of geography of construction had a key impact on the lack of its clear delimitation as one of the sub-disciplines of socio-economic geography; consequently for many years studies dealing with the issues related to the spatial aspects of construction projects were incorporated within related disciplines. An entirely separate and debatable issue is the problem of classification of studies devoted to manufacturing activities related to the production of building materials, which in itself is not a component of the construction process, but significantly conditions it and thus to some extent constitutes its extension.

The problem of construction defined as the field of human activity associated with the erection of buildings, including redevelopment, reconstruction, modernisation and conservation of the existing facilities, was prevalent in many studies published after World War II, although often mentioned briefly as part of settlements issues or the problems of selected business sectors. Although 'explicitly' not referred to as geography of construction, a series of analyses were in fact devoted to investment issues related to this geography sub-discipline, whose basic element is construction investments, covering both the industrial and infrastructural spheres, as well as housing construction.

\section{Main ReSEARCH DiRECTIONS OF Polish GEOgRAPHy OF CONSTRUCTION}

As previously mentioned, the classification of construction can be made, among others, based on its purpose and functions. Taking into account this criterion, it can be concluded that the housing construction has become of particular interest for geographers representing various academic centres in Poland, which results both from its importance for the national economy and the functioning of society. The complexity of problems related to this sector of the economy affects the fact that the subject of housing construction has been undertaken in many academic studies, as well as specialist and daily press, among others due to significant transformations that affected this sector in Poland during the period of the centrally planned economy, and then during the political and economic transformation.

Studies in the field of geography of construction include problems of housing development and changes in its spatial concentration (Tkocz, 1993; Gaczek, Rykiel, 1999; Marszał, 1999a, 1999c; Pieniążek, 2005; Milewska, Ogrodowczyk, 2006a; Tkocz, 2010; Stępniak, 2014). They also analyse the quantitative development of housing construction against the background of national policy in those terms (Marszał, Juraś, 1998; 
Ilnicki, 1999a, 1999c, 2003; Juraś, Posatskyy, 1999; Marszał, 1999b; Marszał, Stawasz, 2006a, 2006b; Ogrodowczyk, 2015). The influence of spatial policy and changes in the construction law on the development of new housing construction is also underlined (Milewska, 2003a, 2003b; Borowska, 2011; Ogrodowczyk, 2011b). The specificity of construction, including its sensitivity to economic fluctuations, favours interest in the relationships that exist between housing and the economy, as well as the state's tax policy.

The emergence of new forms of financing and supporting the development of housing construction in the conditions of market economy means that analyses devoted to this sector also concern its changing investment structure, as well as problems in the management of housing resources, occurring especially in the new socio-economic conditions (Marszał, 2000; Marszał, Stawasz, 2006a, 2006b).

Important themes of analyses are still the directions of technological development in the construction industry and the problems of standard and technical equipment of housing resources and their exploitation, as well as problems of modernisation and revitalisation in connection with often unsatisfactory technical condition of residential buildings (Kozłowski, 2005; Słodczyk, Jakubczyk, 2005).

The issues of the location of new housing constructions in urban areas are rarely described in detail in the literature. They appear as part of wider problems, especially in the context of spatial development conditions of various types of housing, as well as in the area of acquisition of land for investment and selection of a detailed location of new housing, also in the form of housing estates (Gaczek, Rykiel, 1999; Słodczyk, Klimek, 2003; Wdowicka, 2007; Ogrodowczyk, 2011a). The directions of spatial development of housing, also in connection with changes in infrastructure of urban areas (Bartosiewicz, Turczyn, 2008) and the spatial structure of housing (Dzieciuchowicz, 2002; Milewska, 2008) are also analysed. It is worth noting that new housing construction is of interest for geographers in the context of its impact on social transformations taking place in urban areas, including processes of gentrification (Holm, Marcińczak, Ogrodowczyk, 2015).

The majority of studies in the field in question is related to the issues of housing development, structures of residential spaces and housing conditions of the population, especially residing in large cities and suburban areas (Dzieciuchowicz, 1974, 1975, 2002; Gaczek, 1979; Tkocz, 1992; Jakóbczyk-Gryszkiewicz, 1995, 1998; Ilnicki, 1996, 2001, 2006; Kaczmarek, 1996; Gotowski, 2003; Milewska, Molenda, 2004; Matykowski, Tobolska, 2005; Milewska, 2005, 2008; Ogrodowczyk, 2006; Milewska-Osiecka, 2010, $2011,2015)$, as well as the broadly understood theme of value and the real estate market (Groeger, 2004), while publications on the housing development of medium and small towns are definitely less numerous. In particular, they deal with the topic of conditions for the development of housing construction, as well as the types of buildings located within these urban centres (Kaczmarek, 1991; Jażdżewska, 1998; Lamprecht, 2003; Konecka-Szydłowska, 2006; Zaniewska, Barek, 2005; Ogrodowczyk, 2005/2006; Milewska-Osiecka, Ogrodowczyk, 2006b) and implementation of various types of construction projects in their areas (Milewska, Turczyn, 2005; Turczyn, 2005, 2016; Durecka, Durecki, 2015; Węcławowicz-Bilska, 2015). If compared to the studies referring to the problem of housing construction in cities, those related to national scale (Marszał, 1999b; Ilnicki, 2003) are not numerous. 
In the second half of the 20th century, construction investments with an industrial function were the object of interest of geography of construction, among others in the context of their planning (Knyziak, Lissowski, 1964), location (Opałło 1963, 1978), and the development of the building materials industry (Gajowski, 1958; Misztal, 1958; Najgrakowski, Grzeszczak, 1959; Grzeszczak, 1962, 1964; Bolkowski, 1966, 1968). Research in the field of industrial investment development was often conducted not only at regional, but also national level (Szerwentke, 1962; Balcerska, 1971). In geographical literature, the location of industrial investments is also undertaken (e.g. Kistowski, 2012).

Publications in the field of geography of construction are also devoted to the issues of construction investments with a service function (in this case, it is possible to talk about close links with the object of research of geography of services). One can distinguish those that treat the services sector as a whole, not taking into account its differentiation (Śleszyński, 2006; Nowak, Turczyn, 2009), and those in which attention is devoted to the selected objects, e.g. based on a functional criterion (Micek, 2003; Gwosdz, Sobala-Gwosdz, 2008; Stryjakiewicz, 2009; Kowalski, Wiśniewski, 2017).

A large group of studies from the discussed topic is devoted to the problem of construction investments with various functions, especially in urban areas (Broniewski, 1978; Marszał, 2003; Śleszyński, 2008; Jarczewski, 2008). Geographical research on this subject, conducted during the centrally planned economy, concerned, inter alia, distribution of investment expenditures (Eberhard, 1975), but the issue of location of the investment and its conditions was a particularly important issue (Pyszkowski, 1976; Zajda, Szlachta, 1982). Contemporary studies in this field have quite a diverse subject matter - they relate to, among others issues, the structure of implemented investments and their impact on urban development (Bartosiewicz, Turczyn, 2008), acquisition of new investment areas (Mazur, 2005), as well as social effects of investment implementation (Szmytkowska, 2003; Bednarek-Szczepańska, Dmochowska-Dudek, 2016). It is worth emphasising an increased interest in investments in the field of communication/ road construction (Komornicki, Śleszyński, 2009; Rosik, 2010; Ciechański, 2013; Rosik, Kowalczyk, 2015; Komornicki et al., 2015).

Taking into account the scope of the issues of the discipline defined in the article and studies undertaken by geographers in this regard, we can distinguish some research directions of geography of construction in Poland, focusing on the following issues:

- conditions of the development of construction of different functions both at national and local level (with particular emphasis on legal and institutional conditions);

- development of construction, especially in the context of phenomena accompanying this economic activity, including those in the sphere of social cohesion;

- location factors and effects of construction projects with different functions;

- spatial structure of construction projects;

- relationships between construction projects and the surrounding geographical environment.

Among the publications that can be listed as achievements of geography of construction are also studies addressing theoretical and methodological issues, with this current of research being rather poorly represented in Polish literature of the subject. Geography of construction, as a young sub-discipline of geographical sciences, in the field of theoretical approaches and research methodology utilises in a broad sense 
achievements of socio-economic geography and other fields of knowledge, which is emphasised by the already mentioned, interdisciplinary character of the spatial research devoted to this branch of national economy.

\section{FINAL REMARKS}

The current state of Polish geography of construction is a consequence of both the evolution of the scientific discipline itself and the institutional and economic changes taking place in Poland in recent decades. The importance of geography of construction in the general achievements of geographic sciences in Poland in the last decades has undergone significant changes. In the last quarter of the century, a more explicit separation of this sub-discipline occurred, as evidenced by a quite significant number of worthy publications since 1990, undertaking complex themes of construction investments, especially in the context of their functional and spatial diversity.

In quantitative terms, in the second half of the 20th century, a large group of studies were related to industrial construction, including, among others, the issues of conditions and location factors, and its relationship with the development of the industry of building materials. Another important issue analysed in geographic literature at that time was investments in housing, which was probably related to the level of unmet housing needs of the population, especially in large urban centres, during the centrally planned economy.

The last two decades have brought greater thematic diversity of the research issues implemented within geography of construction, conditioned by the changes which after 1990 were brought by the socio-economic processes, progressive globalisation and tertiarisation of the economy, technological development and rapidly changing needs of the society. In addition to the traditionally undertaken issues in geographic studies, the issues of municipal housing and services construction were discussed, rather sporadically referred to in the past. Nonetheless, housing investments are still a significant research topic, whose development and location are analysed in various contexts, often on the border with other scientific disciplines.

Functionally differentiated construction investments remain an important object of research of geographers in Poland. This is evidenced by the rich published scientific output and a number of presentations at conferences devoted to this subject (often seen in its entire interdisciplinary dimension), as well as some successful doctoral dissertations dealing with construction issues in spatial terms. The results of research conducted in this field have contributed in a significant way to better recognition of the conditions and course of socio-economic transformation in Poland in various contexts and various spatial scales.

\section{References}

Balcerska, H. (1971). Struktura przestrzenna nakładów inwestycyjnych a rozwój przemysłu w ostatnim 10-leciu [Spatial structure of investment outlays and industrial development in the last 10 years]. Gospodarka Planowa, 9, 545-548.

Bartosiewicz, B., Turczyn, M. (2008). Struktura komunalnych inwestycji infrastrukturalnych oraz inwestycji budowlanych i ich wpływ na kierunki rozwoju przestrzennego najmniejszych miast województwa łódzkiego [The structure of municipal infrastructure investments and construction investments and their impact on the directions of spatial development 
of the smallest towns of the Łódzkie Voivodeship]. In: K. Heffner (ed.). Współczesne problemy rozwoju ośrodków lokalnych [Contemporary problems of development of local centers]. Katowice: Wydawnictwo Akademii Ekonomicznej w Katowicach, 317-331.

Bednarek-Szczepańska, M., Dmochowska-Dudek, K. (2016). Syndrom nimby na obszarach wiejskich: Uwarunkowania i specyfika konfliktów wokół lokalizacji niechcianych inwestycji [The NIMBY syndrome in rural areas: Conditions and specificity of conflicts around the location of unwanted investments]. Prace Geograficzne, 255.

Bolkowski, J. (1966). Problemy rozwoju przemysłu materiałów budowlanych w latach 19661970 [Problems of the development of the building materials industry in 1966-1970]. Gospodarka Planowa, 3.

Bolkowski, J. (1968). Perspektywiczne kierunki rozwoju przemysłu materiałów budowlanych, szklarskiego i ceramiki szlachetnej [Perspective development directions of the building, glass and precious ceramics industries]. Inwestycje i Budownictwo, 7/8.

Borowska, M. (2011). Procesy budowlane w Łodzi w sytuacji braków miejscowych planów zagospodarowania [Construction processes in Łódź in the absence of local development plans]. Acta Scientarium Polonorum, 10(3), 19-38.

Broniewski, S. (1978). Rozmieszczenie inwestycji w miastach [Distribution of investments in cities]. Warszawa: Polskie Wydawnictwo Ekonomiczne.

Ciechański, A. (2013). Rozwój i regres sieci kolei przemysłowych w Polsce (1881-2010) w świetle materiałów archiwalnych [Development and regress of the industrial railway network in Poland (1881-2010) in the light of archival materials]. Prace Geograficzne, 243.

Durecka, I., Durecki, T. (2015). Wpływ inwestycji z dofinansowaniem unijnym na rozwój przestrzenny w wybranych miastach aglomeracji łódzkiej. Acta Universitatis Lodziensis Folia Geographica Socio-Oeconomica, 19, 149-165.

Dzieciuchowicz, J. (1974). Rozwój budownictwa mieszkaniowego w Łodzi w latach 1945-1965 oraz jego wpływ na zmiany warunków mieszkaniowych ludności [Development of housing in Łódź in the years 1945-1965 and its impact on changes in housing conditions of the population]. Zeszyty Naukowe Uniwersytetu Łódzkiego, 55, 31-47.

Dzieciuchowicz, J. (1975). Kształtowanie warunków środowiska mieszkaniowego wielkiego miasta na przykładzie Łodzi [Shaping the housing conditions of a big city on the example of Łódź]. In: XIII Ogólnopolski Zjazd PTG, Tezy i streszczenia referatów [XIII National Congress of the Polish Geographical Association, Theses and summaries of papers]. Łódź, 66-68.

Dzieciuchowicz, J. (2002). Zasoby mieszkaniowe Łodzi: rozwój, struktura przedmiotowa i przestrzenna [Housing resources of Łódź: development, and objective and spatial structure]. Acta Universitatis Lodziensis Folia Geographica Socio-Oeconomica, 4, 47-65.

Eberhardt, P. (1975). Rozmieszczenie nakładów inwestycyjnych w okresie 1960-1970 [Distribution of investment outlays in the period 1960-1970]. Biuletyn Komitetu Przestrzennego Zagospodorowania Kraju Polskiej Akademii Nauk, 87, 147-184.

Gaczek, W.M. (1979). Struktura przestrzeni rezydencjalnej Poznania [The structure of the residential space of Poznań]. Warszawa-Poznań: Wydawnictwo Naukowe PWN.

Gaczek, W.M., Rykiel, Z. (1999). Nowe lokalizacje mieszkaniowe w przestrzeni miasta. [New housing locations in urban space]. Biuletyn Komitetu Przestrzennego Zagospodorowania Kraju Polskiej Akademii Nauk, 190, 29-47.

Gajowski, S. (1958). Perspektywy rozwoju przemysłu materiałów budowlanych w woj. warszawskim i m. st. Warszawie [Prospects for the development of the building materials industry in the Warsaw Voivodeship and the capital city of Warsaw]. Materiały Budowlane, 8, 232-237.

Gotowski, R. (2003). Budownictwo jednorodzinne na obszarze gminy Białe Błota w aspekcie procesu suburbanizacji [Single-family housing in the area of Białe Błota gmina in the aspect of the suburbanisation process]. In: T. Marszał (ed.). Budownictwo w przestrzeni lokalnej [Construction in the local space]. Łódź: Wydawnictwo Uniwersytetu Łódzkiego, 117-122.

Groeger, L. (2004). Waloryzacja przestrzeni mieszkaniowej w opiniach klientów łódzkich biur obrotu nieruchomościami [Valorisation of the housing space in the opinions of clients of Łódź real estate offices]. Łódź: Wydawnictwo Uniwersytetu Łódzkiego.

Grzeszczak, J. (1962). Problemy gospodarki surowcowej przemysłu ceramiki budowlanej w Polsce [Problems of raw materials management in the construction ceramics industry in Poland]. Biuletyn Komitetu Przestrzennego Zagospodorowania Kraju Polskiej Akademii Nauk, 5(14). 
Grzeszczak, J. (1964). Zagadnienia wodne i klimatyczne w przemyśle cegielnianym [Water and climate issues in the brick industry]. Dokumentacja Geograficzna, 6, 63-82.

Gwosdz, K., Sobala-Gwosdz, A. (2008). Geografia hipermarketów w Polsce: strategie lokalizacyjne firm i ich skutki przestrzenne [Geography of hypermarkets in Poland: location strategies of companies and their spatial effects]. Przeglad Geograficzny, 80(4), 276-290.

Holm, A., Marcińczak, S., Ogrodowczyk, A. (2015). New-build gentrification in the post-socialist city: Łódź and Leipzig two decades after socialism. Geografie, 120(2), 164-187.

Ilnicki, D. (1996). Proces suburbanizacji w aglomeracji wrocławskiej na przykładzie budownictwa mieszkaniowego [The suburbanisation process in the Wrocław agglomeration on the example of housing construction]. Studia Geograficzne, 65.

Ilnicki, D. (1999). Przestrzeń budowlana Dolnego Śląska [Construction space of Lower Silesia]. Biuletyn Komitetu Przestrzennego Zagospodorowania Kraju Polskiej Akademii Nauk, 190, 91-104.

Ilnicki, D. (2000a). Charakterystyka przestrzeni budowlanej Dolnego Śląska w latach 1994-1997 [Characteristics of the construction space of Lower Silesia in the years 1994-1997]. Studia Regionalne nad Rozwojem Dolnego Sląska [Regional Studies on the Development of Lower Silesia], 1, 98-110.

Ilnicki, D. (2000b). Warunki mieszkaniowe jako wyraz poziomu i jakości życia ludności Dolnego Śląska [Housing conditions as an expression of the level and quality of life of the Lower Silesia population]. Studia Regionalne nad Rozwojem Dolnego Ślaska [Regional Studies on the Development of Lower Silesia], 1, 83-97.

Ilnicki, D. (2001). Inwestycje mieszkaniowe w przestrzeni Wrocławia [Housing investments in the space of Wroclaw]. In: Miasto postsocjalistyczne - organizacja przestrzeni miejskiej i jej przemiany (cz. II) [Post-socialist city - organisation of urban space and its transformation (part II)]. Łódź: Wydawnictwo Uniwersytetu Łódzkiego, 221-235.

Ilnicki, D. (2003). Zmiany i przestrzenne zróżnicowanie budownictwa mieszkaniowego w Polsce w latach dziewięćdziesiątych [Changes and spatial diversification of housing construction in Poland in the 1990]. In: T. Marszał (ed.). Budownictwo w przestrzeni lokalnej [Construction in the local space]. Łódź: Wydawnictwo Uniwersytetu Łódzkiego, 7-22.

Ilnicki, D. (2006). Rozwój przestrzeni rezydencjalnej Wrocławia [The development of the residential space of Wrocław]. Biuletyn Komitetu Przestrzennego Zagospodorowania Kraju Polskiej Akademii Nauk, 227, 36-54.

Jakóbczyk-Gryszkiewicz, J. (1995). Procesy zachodzące w strefach podmiejskich dużych miast. Przykład strefy podmiejskiej Warszawy, Łodzi i Krakowa [Processes occurring in suburban zones of large cities. An example of the suburban area of Warsaw, Łódź and Kraków]. Acta Universitatis Lodziensis, Folia Geographica, 20, 221-228.

Jakóbczyk-Gryszkiewicz, J. (1998). Przeobrażenia stref podmiejskich dużych miast, Studium porównawcze strefy podmiejskiej Warszawy, Łodzi i Krakowa [Transformation of suburban zones of large cities. Comparative study of the suburban zone of Warsaw, tódź and Kraków]. Łódź: Wydawnictwo Uniwersytetu Łódzkiego.

Jarczewski, W. (2008). Atrakcyjność inwestycyjna a rozmieszczenie inwestycji zagranicznych w małopolskich gminach [Investment attractiveness and the distribution of foreign investments in Małopolska gminas]. Przegląd Geograficzny, 80(2), 223-242.

Jażdżewska, I. (1998). Przemiany funkcjonalne i przestrzenne zabudowy osady Rzgów w latach 1920-1995 [Functional and spatial changes in the development of the Rzgów settlement in the years 1920-1995]. In: J. Kaczmarek (ed.). Metodologia geografii osadnictwa na przełomie wieków, X Konwersatorium Wiedzy o Mieście [Methodology of the settlement geography at the turn of the century, X Seminar of Knowledge about the City]. Łódź: Wydawnictwo Uniwersytetu Łódzkiego, 131-135.

Juraś, J., Posatskyy, B. (1999). Przemiany przestrzenne w budownictwie mieszkaniowym Lwowa w latach 90. [Spatial changes in housing construction in Lviv in the 1990s]. Biuletyn Komitetu Przestrzennego Zagospodorowania Kraju Polskiej Akademii Nauk, 190, 139-145.

Kaczmarek, J. (1991). Indywidualne budownictwo mieszkaniowe jako miernik ekspansji miasta na tereny wiejskie [Individual housing construction as a measure of the city's expansion into rural areas]. Acta Universitatis Lodziensis, Folia Geographica, 14, 171-177. 
Kaczmarek, S. (1996). Struktura przestrzenna warunków zamieszkania w Łodzi [Spatial structure of living conditions in Łódź]. Szlakami Nauki [On the routes of science], 23.

Kistowski, M. (2012). Propozycja metodyczna oceny środowiskowych uwarunkowań lokalizacji farm wiatrowych w skali regionalnej [Methodological proposal for the assessment of environmental conditions of the location of wind farms on a regional scale]. Przeglad Geograficzny, 84(1).

Knyziak, Z., Lissowski, W. (1964). Ekonomika i programowanie inwestycji przemysłowych [Economics and programming of industrial investments]. Warszawa: Wydawnictwo Naukowe PWN.

Komornicki, T., Śleszyński, P. (ed.). (2009). Studia nad lokalizacją regionalnych portów lotniczych na Mazowszu [Studies on the location of regional airports in Mazovia]. Prace Geograficzne, 220.

Komornicki, T., Wiśniewski, R., Baranowski, J., Błażejczyk, K., Degórski, M., Goliszek, S., Rosik, P., Solon, J., Stępniak, M., Zawiska, I. (2015). Wpływ korytarzy drogowych na środowisko przyrodnicze i rozwój społeczno-gospodarczy [The impact of road corridors on the natural environment and socio-economic development]. Prace Geograficzne, 249.

Konecka-Szydłowska, B. (2006). Wzrost ludnościowy i rozwój budownictwa mieszkaniowego w miastach strefy podmiejskiej Poznania [Population growth and development of housing in cities in the suburban zone of Poznań]. Biuletyn Komitetu Przestrzennego Zagospodorowania Kraju Polskiej Akademii Nauk, 226.

Kowalski, M., Wiśniewski, S. (2017). Centrum handlowe jako czynnik ruchotwórczy w transporcie samochodowym - przykład Portu Łódź [Shopping center as a traffic factor in road transport - an example of the Port of Łódź]. Przegląd Geograficzny, 89(4), 617-639.

Kozłowski, S. (2005). Możliwości modernizacji osiedli wielkopłytowych [Possibilities of modernisation of large-panel housing estates]. Biuletyn Komitetu Przestrzennego Zagospodorowania Kraju Polskiej Akademii Nauk, 216, 127-143.

Lamprecht, M. (2003). Wielorodzinne budownictwo w Kole [Multi-family housing in Koło]. In: T. Marszał (ed.). Budownictwo w przestrzeni lokalnej [Construction in the local space]. Łódź: Wydawnictwo Uniwersytetu Łódzkiego, 69-79.

Marszał, T. (ed.) (1999a). Budownictwo mieszkaniowe w latach dziewięćdziesiątych - zróżnicowanie przestrzenne i kierunki rozwoju [Housing construction in the 1990s - spatial diversification and development directions]. Biuletyn Komitetu Przestrzennego Zagospodorowania Kraju Polskiej Akademii Nauk, 190.

Marszał, T. (1999b). Zróżnicowanie i kierunki rozwoju budownictwa mieszkaniowego w Polsce [Diversity and directions of housing development in Poland]. Biuletyn Komitetu Przestrzennego Zagospodorowania Kraju Polskiej Akademii Nauk, 190, 7-28.

Marszał, T. (1999c). Struktura przestrzenna wielorodzinnego budownictwa mieszkaniowego w Łodzi w latach 90. [Spatial structure of multi-family housing in Łódź in the 1990s]. Biuletyn Komitetu Przestrzennego Zagospodorowania Kraju Polskiej Akademii Nauk, 190, 69-90.

Marszał, T. (2000). Social and co-operative housing in Łódź - developments in the period of transition. In: T. Marszał (ed.). Local economy and urban development in Poland. Łódź.

Marszał, T. (2001). Polska geografia przemysłu i budownictwa w XX w. - sylwetki [Polish geography of industry and construction in the twentieth century - silhouettes]. Łódź- WarszawaKraków.

Marszał, T. (ed.) (2003). Budownictwo w przestrzeni lokalnej [Construction in the local space]. Łódź: Wydawnictwo Uniwersytetu Łódzkiego.

Marszał, T., Juraś, J. (1998). The housing sector in Poland - new developments in the period of transition to a market economy. In: A. Holt-Jensen, N. Morrison (ed.). Social housing: International comparison of planning for the weakest social groups, 3, 127-142.

Marszał, T., Stawasz, D. (2006a). Budownictwo mieszkaniowe w polskich miastach po 1990 r. stan i trendy rozwoju [Housing construction in Polish cities after 1990 - state and development trends]. Biuletyn Komitetu Przestrzennego Zagospodorowania Kraju Polskiej Akademii Nauk, 227, 8-19.

Marszał, T., Stawasz, D. (ed.) (2006b). Przestrzeń rezydencjalna w miastach polskich [Residential space in Polish cities]. Biuletyn Komitetu Przestrzennego Zagospodorowania Kraju Polskiej Akademii Nauk, 227. 
Matykowski, R., Tobolska, A. (2005). Nowe inwestycje przemysłowe i mieszkaniowe w gminie Tarnowo Podgórne w strefie podmiejskiej Poznania [New industrial and residential investments in the Tarnowo Podgórne gmina in the suburban area of Poznań]. Biuletyn Komitetu Przestrzennego Zagospodorowania Kraju Polskiej Akademii Nauk, 216, 98-111.

Mazur, K. (2005). Pozyskiwanie nowych terenów inwestycyjnych w strukturze miasta [Acquiring new investment areas in the city structure]. Biuletyn Komitetu Przestrzennego Zagospodorowania Kraju Polskiej Akademii Nauk, 216, 162-172.

Micek, G. (2003). Nowe inwestycje biurowe w Krakowie [New office investments in Kraków]. In: T. Marszał (ed.). Budownictwo w przestrzeni lokalnej [Construction in the local space]. Łódź: Wydawnictwo Uniwersytetu Łódzkiego, 80-96.

Milewska, K. (2003a). Prawno-instytucjonalne uwarunkowania budownictwa mieszkaniowego na szczeblu lokalnym - wybrane przykłady [Legal and institutional determinants of housing construction at the local level - selected examples]. In: T. Marszał (ed.). Budownictwo w przestrzeni lokalnej [Construction in the local space]. Łódź: Wydawnictwo Uniwersytetu Łódzkiego, 23-40.

Milewska, K. (2003b). Problematyka budownictwa mieszkaniowego w studiach uwarunkowań i kierunków zagospodarowania przestrzennego na przykładzie gmin aglomeracji łódzkiej [Problems of housing construction in the study of conditions and directions of spatial development on the example of gminas in the Łódź agglomeration]. Biuletyn Komitetu Przestrzennego Zagospodorowania Kraju Polskiej Akademii Nauk, 203, 61-78.

Milewska, K. (2005). Zabudowa plombowa jako element zagospodarowania centrum Łodzi - przykład ulicy Piotrkowskiej[Infill construction as part of the development of the center of Łódź - an example of Piotrkowska Street]. Biuletyn Komitetu Przestrzennego Zagospodorowania Kraju Polskiej Akademii Nauk, 216, 144-161.

Milewska, K. (2008). Struktura przestrzenna nowego budownictwa mieszkaniowego aglomeracji łódzkiej [The spatial structure of the new housing industry of the Łódź agglomeration]. Mpis pracy doktorskiej w Uniwersytecie Łódzkim [Script of a dissertation thesis at the University of Lodz].

Milewska, K., Molenda, J. (2004). Budownictwo mieszkaniowe na obszarze Parku Krajobrazowego Wzniesień Łódzkich i jego wpływ na zmiany w zagospodarowaniu przestrzeni - przykład gminy Nowosolna [Housing construction in the Łódzkie Hills Landscape Park and its impact on changes in the development of space - an example of the Nowosolna gmina]. In: K. Heffner, T. Marszał (ed.). Gospodarka w przestrzeni lokalnej. Środowiskowe uwarunkowania rozwoju lokalneg [Economy in the local space. Environmental determinants of local development]. Łódź: Wydawnictwo Uniwersytetu Łódzkiego, 119-142.

Milewska, K., Turczyn, M. (2005). Uwarunkowania rozwoju i struktura nowych inwestycji budowlanych na obszarze małego miasta aglomeracji łódzkiej - przykład Strykowa [Determinants of development and structure of new construction investments in the area of a small town in the Łódź agglomeration - Stryków's example]. In: K. Heffner (ed.). Małe miasta a rozwój lokalny i regionalny [Small towns and local and regional development]. Katowice: Wydawnictwo Akademii Ekonomicznej, 311-326.

Milewska-Osiecka, K. (2010). Budownictwo mieszkaniowe aglomeracji łódzkiej [Housing construction of the Łódź agglomeration]. Łódź: Wydawnictwo Uniwersytetu Łódzkiego.

Milewska-Osiecka, K. (2011). Fizjonomia i układy urbanistyczne nowego budownictwa mieszkaniowego jako element kształtowania warunków mieszkaniowych (na wybranych przykładach) [Physiognomy and urban layouts of new housing as an element of shaping housing conditions (on selected examples)]. Economy, Space - Society - Economy, 10, 59-82.

Milewska-Osiecka, K. (2015). New housing in the municipal lad-policy context - Lodz agglomeration case study. Journal of Economics and Management, 19(1), 155-172.

Milewska-Osiecka, K., Ogrodowczyk, A. (2006a). Struktura budownictwa wielorodzinnego na obszarze Łodzi [The structure of multi-family housing in the area of Łódź]. Biuletyn Komitetu Przestrzennego Zagospodorowania Kraju Polskiej Akademii Nauk, 227, 99-113.

Milewska-Osiecka, K., Ogrodowczyk, A. (2006b). Budownictwo mieszkaniowe w małych miastach woj. łódzkiego [Housing construction in small towns of Łódzkie Voivodeship]. Biuletyn Komitetu Przestrzennego Zagospodorowania Kraju Polskiej Akademii Nauk, 227, 181-199. 
Misztal, S. (1958). Problem zaopatrzenia Warszawy i województwa warszawskiego w podstawowe materiały budowlane [The problem of supplying Warsaw and the Warsaw Voivodeship with basic building materials]. Inwestycje i Budownictwo, 10, 30-34.

Misztal, S., Zioło, Z. (ed.) (1998). Dorobek polskiej geografii przemysłu w badaniach ośrodków akademickich [Achievements of the Polish industry geography in the research of academic centers]. Warszawa-Kraków: Wydawnictwo Polskiej Akademii Nauk Kraków.

Najgrakowski, M., Grzeszczak, J. (1959). Próba rejonizacji produkcji ceramiki budowlanej w Polsce w 1956 r. [An attempt to regionalise the production of building ceramics in Poland in 1956]. Przegląd Geograficzny, 31(1), 67-91.

Nowak, A., Turczyn, M. (2009). Nowe inwestycje usługowe na tle rozwoju funkcji usługowej w małych miastach województwa łódzkiego od roku 1995 [New service investments compared to the development of a service function in small towns of Łódzkie Voivodeship since 1995]. In: T. Marszał (ed.). Funkcja usługowa małych miast [Small towns service function]. Łódź: Wydawnictwo Uniwersytetu Łódzkiego, 7-30.

Ogrodowczyk, A. (2005/2006). Budownictwo mieszkaniowe jako element zagospodarowania przestrzeni miejskiej Tuszyna [Housing construction as part of the development of the urban space of Tuszyn]. In: K. Heffner, T. Marszał (ed.). Małe miasta - studium przypadków [Small towns - case studies]. Łódź, 129-142.

Ogrodowczyk, A. (2006). Budownictwo mieszkaniowe w strefie podmiejskiej Łodzi - przykład gminy Nowosolna [Housing construction in the suburban area of Łódź - an example of the Nowosolna gmina]. In: T. Marszał (ed.). Łódź - wybrane zagadnienia zagospodarowania przestrzennego [Łódź - selected issues of spatial development]. Łódź: Wydawnictwo Uniwersytetu Łódzkiego, 213-226.

Ogrodowczyk, A. (2011a). Nowe budownictwo mieszkaniowe w przestrzeni małych miast Polski Środkowej - lokalizacja i uwarunkowania rozwoju [New housing construction in the space of small towns of Central Poland - location and conditions of development]. Łódź: Mpis pracy doktorskiej w Uniwersytecie Łódzkim [Script of a dissertation thesis at the University of Lodz].

Ogrodowczyk, A. (2011b). Polityka przestrzenna a rozwój budownictwa mieszkaniowego po 1990 roku na przykładzie małych miast w województwie łódzkim [Spatial policy and the development of housing construction after 1990 on the example of small towns in Łódzkie Voivodeship]. Acta Universitatis Lodziensis. Folia Geographica-Socio Oeconomica, 11, 167186.

Ogrodowczyk, A. (2015). Spatial Aspects of housing policy transformations in Poland after 1989 - example from Lodz. Journal of Economics and Management, 19(1), 137-154.

Opałło, M. (1963). Zadania w zakresie lokalizacji inwestycji przemysłowych w planie 1966-1970 (wkładka) [Tasks for the location of industrial investments in the plan 1966-1970 (insert)]. Gospodarka i Administracja Terenowa.

Opałło, M. (1978). Programowanie rozmieszczenia przemysłu a wybór lokalizacji inwestycji [Programming the location of the industry and choosing the location of the investment]. Prace Instytutu Planowania, 49.

Pieniążek, M. (2005). Wpływ ruchu budowlanego na przekształcenia struktur przestrzennych wybranych miast województwa mazowieckiego [The influence of building traffic on the transformation of spatial structures of selected cities in Mazowieckie Voivodeship]. Prace i Studia Geograficzne, 35, 87-107.

Pyszkowski, A. (1976). Tryb lokalizacji inwestycji a planowanie przestrzenne [Investment location mode versus spatial planning]. Miasto, 6, 1-3.

Rosik, P. (2009). Syntetyczna ocena drogowego i kolejowego wyposażenia infrastrukturalnego województw [Synthetic assessment of road and rail infrastructure equipment of voivodeships]. Przegląd Geograficzny, 81(4), 507-526.

Rosik, P., Kowalczyk, K. (2015). Rozwój infrastruktury drogowej i kolejowej a przesunięcie modalne w Polsce w latach 2000-2010 [Development of road and railway infrastructure and modal shift in Poland in 2000-2010]. Prace Geograficzne, 248.

Słodczyk, J., Jakubczyk, Z. (2005). Rewitalizacja małego miasta w świetle zasad zrównoważonego rozwoju na przykładzie Prudnika [Revitalisation of a small town in the light of the principles of sustainable development on the example of Prudnik]. In: K. Heffner (ed.). Małe miasta 
a rozwój lokalny i regionalny [Small towns versus local and regional development]. Katowice: Wydawnictwo Akademii Ekonomicznej, 281-298.

Słodczyk, J., Klimek, R. (2003). Miejsca lokalizacji nowego budownictwa mieszkaniowego w przestrzeni miasta - na przykładzie Opola [Locations for new residential construction in the city space - on the example of Opole]. In: T. Marszał (ed.). Budownictwo w przestrzeni lokalnej [Construction in the local space]. Łódź: Wydawnictwo Uniwersytetu Łódzkiego, 56-69.

Stępniak, M. (2014). Przekształcenia przestrzennego rozmieszczenia zasobów mieszkaniowych w Warszawie w latach 1945-2008 [Transformation of spatial distribution of housing resources in Warsaw in 1945-2008]. Prace Geograficzne, 245.

Straszewicz, L. (1986). Miejsce i rola geografii przemysłu w systemie nauk i studiów geograficznych [The place and role of the geography of industry in the system of geographic sciences and studies]. Acta Universitatis Lodzienisis. Folia Geographica, 7, 25-33.

Stryjakiewicz, T. (2009). Lokalizacja firm i zachowania przestrzenne pracowników sektora informatycznego (na przykładzie poznańskiego obszaru metropolitalnego) [Location of companies and spatial behaviour of IT sector employees (on the example of the Poznań metropolitan area)]. Prace Komisji Geografii Przemysłu Polskiego Towarzystwa Geograficznego, 13, 21-33.

Szerwentke, A. (1962). Problemy rozwoju inwestycji przemysłowych w PRL w latach 1946-1960. Mpis [Problems of industrial investment development in the Polish People's Republic in 1946-1960. Script]. Warszawa: Komitet Przestrzennego Zagospodorowania Kraju Polskiej Akademii Nauk.

Szmytkowska, M. (2003). Wpływ nowych inwestycji na wizerunek miasta i przestrzeń społeczną Gdyni [Impact of new investments on Gdynia's image and social space]. In: T. Marszał (ed.). Budownictwo w przestrzeni lokalnej. [Construction in the local space]. Łódź: Wydawnictwo Uniwersytetu Łódzkiego, 41-55.

Śleszyński, P. (2006). Przedsiębiorstwa w przestrzeni Warszawy [Enterprises in the area of Warsaw]. Atlas Warszawy [The Atlas of Warsaw], 9.

Śleszyński, P. (2008). Duże przedsiębiorstwa w strukturze przestrzennej największych Polskich miast [Large enterprises in the spatial structure of the largest Polish cities]. Prace Geograficzne, 217.

Tkocz, M. (1992). Wybrane problemy warunków mieszkaniowych w dużych miastach województwa katowickiego [Selected problems of housing conditions in large cities of the Katowice voivodeship]. Wiadomości Statystyczne, 6, 21-24.

Tkocz, M. (1993). Przestrzenne zróżnicowanie terenów mieszkaniowych w miastach Górnośląskiego Okręgu Przemysłowego [Spatial differentiation of residential areas in the cities of the Upper Silesian Industrial District]. Geographia. Studia et Dissertationes, 18, 140150.

Tkocz, M. (2010). Problems of spatial management in cities of the Silesia metropolis with special reference to residential buildings. In.: W. Ratajczak, K. Stachowiak (ed.). Spatial economy for society, 165-174.

Turczyn, M. (2005). Noweinwestycje w małych miastach województwa łódzkiego [New investments in small towns of Łódzkie Voivodeship]. Biuletyn Komitetu Przestrzennego Zagospodorowania Kraju Polskiej Akademii Nauk, 216, 86-97.

Turczyn, M. (2016). Struktura przestrzenna nowych inwestycji budowlanych w małych miastach województwa łódzkiego [Spatial structure of new construction projects in small towns of the Łódzkie Voivodeship]. Maszynopis pracy doktorskiej w Uniwersytecie Łódzkim [Script of a doctoral thesis].

Wdowicka, M. (2007). Lokalizacja nowych osiedli mieszkaniowych w obszarze metropolitalnym Poznania a rozwój małych ośrodków miejskich [The location of new housing estates in the metropolitan area of Poznań versus the development of small urban centers]. Biuletyn Komitetu Przestrzennego Zagospodorowania Kraju Polskiej Akademii Nauk, 232, 48-61.

Węcławowicz-Bilska, E. (2015). Podstawowe rodzaje inwestycji realizowanych w ostatnim dziesięcioleciu w przestrzeni małych miast Małopolski [The basic types of investments carried out over the last decade in the area of small towns of Małopolska]. Acta Universitatis Lodziensis Folia Geographica Socio-Oeconomica, 19, 3-19. 
Zajda, Z., Szlachta, J. (1982). Wstępne wnioski dotyczące teorii i praktyki lokalizacji inwestycji w Polsce w latach 70-tych [Initial conclusions regarding the theory and practice of investment location in Poland in the 1970s]. Biuletyn Komitetu Przestrzennego Zagospodorowania Kraju Polskiej Akademii Nauk, 118, 143-152.

Zaniewska, H., Barek, R. (2005). Zabudowa mieszkaniowa małych miast - przeszłość i teraźniejszość. Rodzaj i stan zasobów mieszkaniowych [Residential housing of small towns past and present. Type and status of housing resources]. In: K. Heffner (ed.). Małe miasta a rozwój lokalny i regionalny [Small towns and local and regional development]. Katowice: Wydawnictwo Akademii Ekonomicznej, 161-168.

Tadeusz Marszał, full professor. His scientific and research interests and the publication themes concern issues in the field of economic geography and spatial economy. They include issues of spatial management and local development, spatial structure of industry and construction, spatial research of minorities, small towns, and regional issues.

\section{Address:}

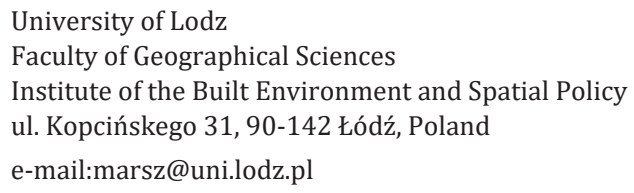

Agnieszka Ogrodowczyk, Ph.D. In her research, she deals with issues of economic geography and spatial economy. Her interests are focused on the spatial structure of construction industry, socio-spatial aspects of housing development, housing inequality, processes leading to cities shrinking, as well as gentrification processes in urban areas.

\section{Address:}

University of Lodz Faculty of Geographical Sciences Institute of the Built Environment and Spatial Policy ul. Kopcińskego 31, 90-142 Łódź, Poland e-mail: agnieszka.ogrodowczyk@geo.uni.lodz.pl 